\title{
Growing Lettuce in Small Hydroponic Systems ${ }^{1}$
}

\section{Germán V. Sandoya, Jonael Bosques, Francisco Rivera, and E. Vanessa Campoverde²}

\section{Introduction}

Lettuce is one of the most consumed vegetables in the United States (USDA NASS 2020) and is mostly eaten in salads and garnishes. In the western United States, lettuce is produced throughout the year and shipped to markets where it may not be available locally. Given that the lettuce may need to travel significant distances from where it was produced, its cultivation and shipment may incur unintended environmental impacts and result in a product with reduced freshness when compared to a locally produced product. From November to April, fresh lettuce can be provided to consumers by Florida farmers. As societal trends highlight carbon footprint and food sustainability, Florida-produced lettuce may carry an advantage that separates it from competitive growers located in states such as California and Arizona. Lettuce produced in controlled environments (CEs), including hydroponic (Figure 1), aquaponic, and vertical growing systems, can provide freshness desired by the consumer in Florida (Tyson, Hochmuth, and Cantliffe 2010). In Florida, there are four large urban areas in which most of the state's population is concentrated. From 2010 to 2019, Florida's population increased $14.2 \%$ to become the third most populated state in the United States (US Census 2019). Therefore, having leafy vegetables produced in CEs could be an alternative method to meet consumer demand for fresh lettuce, especially when produced near or within dense urban areas.

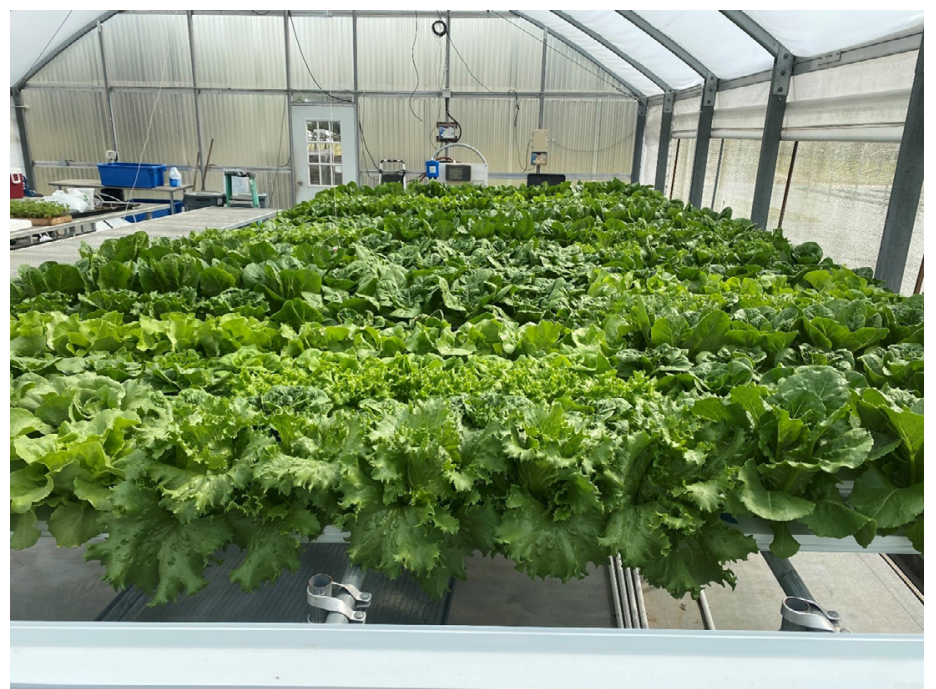

Figure 1. Lettuce grown in a semicommercial hydroponic (Nutrient Film Technique-NFT) system at the UF/IFAS North Florida Research and Education Center-Suwanee Valley near Live Oak, FL. Credits: Germán Sandoya, UF/IFAS

\section{Lettuce Production in Controlled Environments}

Producing vegetables, such as lettuce, in CEs is the art of growing plants without the use of soil, especially when utilizing hydroponic systems. The technique is ancient, evidenced by civilizations that have relied upon this culture method. Historically, hydroponic production has been used by the Aztecs, Incas, Egyptians, Babylonians, and Chinese.

1. This document is HS1422, one of a series of the Horticultural Sciences Department, UF/IFAS Extension. Original publication date September 2021. Visit the EDIS website at https://edis.ifas.ufl.edu for the currently supported version of this publication.

2. Germán V. Sandoya, assistant professor, Horticultural Sciences Department, UF/IFAS Everglades Research and Education Center; Jonael Bosques, county Extension director, UF/IFAS Extension Hardee County; Francisco Rivera, small farms Extension agent, UF/IFAS Extension Hillsborough County; and E. Vanessa Campoverde, commercial agriculture/ornamental Extension agent, UF/IFAS Extension Miami-Dade County; UF/IFAS Extension, Gainesville, FL 32611.

The Institute of Food and Agricultural Sciences (IFAS) is an Equal Opportunity Institution authorized to provide research, educational information and other services only to individuals and institutions that function with non-discrimination with respect to race, creed, color, religion, age, disability, sex, sexual orientation, marital status,

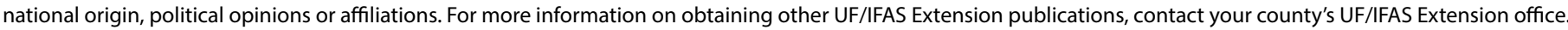
U.S. Department of Agriculture, UF/IFAS Extension Service, University of Florida, IFAS, Florida A \& M University Cooperative Extension Program, and Boards of County Commissioners Cooperating. Nick T. Place, dean for UF/IFAS Extension. 
Modern science named this soilless system "hydroponics" (Greek: "hydro," meaning water; "ponos," working). It has been established by research that soil is not essential for plants to grow. Plants develop and produce in soils only because mineral nutrients are held by soil particles, and soil serves as an anchor for roots to develop and produce normal upward growth. Nutritionally, a proportion of the mineral nutrients found in the soil are in fact unleashed through the action of bacteria, fungi, and worms present in this growth medium. Nutrients slowly dissolve in the surrounding soil or water solution, and the roots then absorb them. All plants have the same basic elemental needs whether they are grown in soil or not. Today, home gardeners could produce their own lettuce for self-consumption in their backyards or inside their homes in small (or limitedspaced) CEs. Producing lettuce in hydroponic systems at home is generally feasible (Figure 2), but home gardeners should take into consideration several aspects prior to growing their own lettuce. These aspects include the type of system, appropriate lighting, nutrition, appropriate cultivar selection, and other key factors explained below. This publication is intended for individuals interested in producing their own lettuce in small hydroponic settings. The content of this publication is also intended to help with planning and selecting a hydroponic system for residential, or "at-home" use.

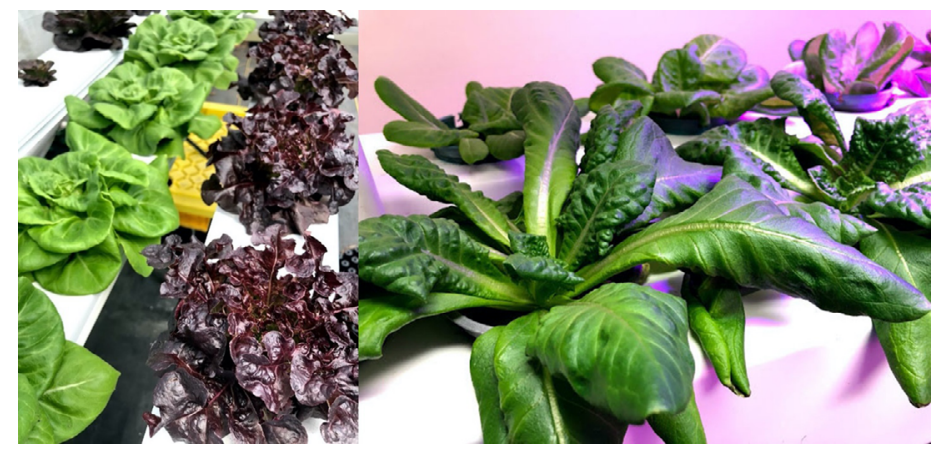

Figure 2. Lettuce grown in two prefabricated Nutrient Film Technique (NFT) small hydroponic systems.

Credits: Jonael Bosques, UF/IFAS

\section{General Considerations}

- Choose the right hydroponic system (see below for a description of available systems).

- Plant a lettuce cultivar adapted to shorter day length and warmer conditions.

- Become familiar with your plants and system. Keeping a detailed record of any procedures and/or changes made during each season might help prevent future issues.

- Regular scouting will prevent pests and diseases from establishing and destroying your leafy crops.
- Contact your local UF/IFAS Extension agent for additional guidelines.

\section{Specific Considerations}

Growing media. Choose the right media to grow your hydroponic lettuce crop. There are many types of media on the market, including rock wool, perlite, composted pine bark, and coconut fiber. Other substrates that can be used as media include river rock and light expanded clay aggregate (LECA) (Figure 3).

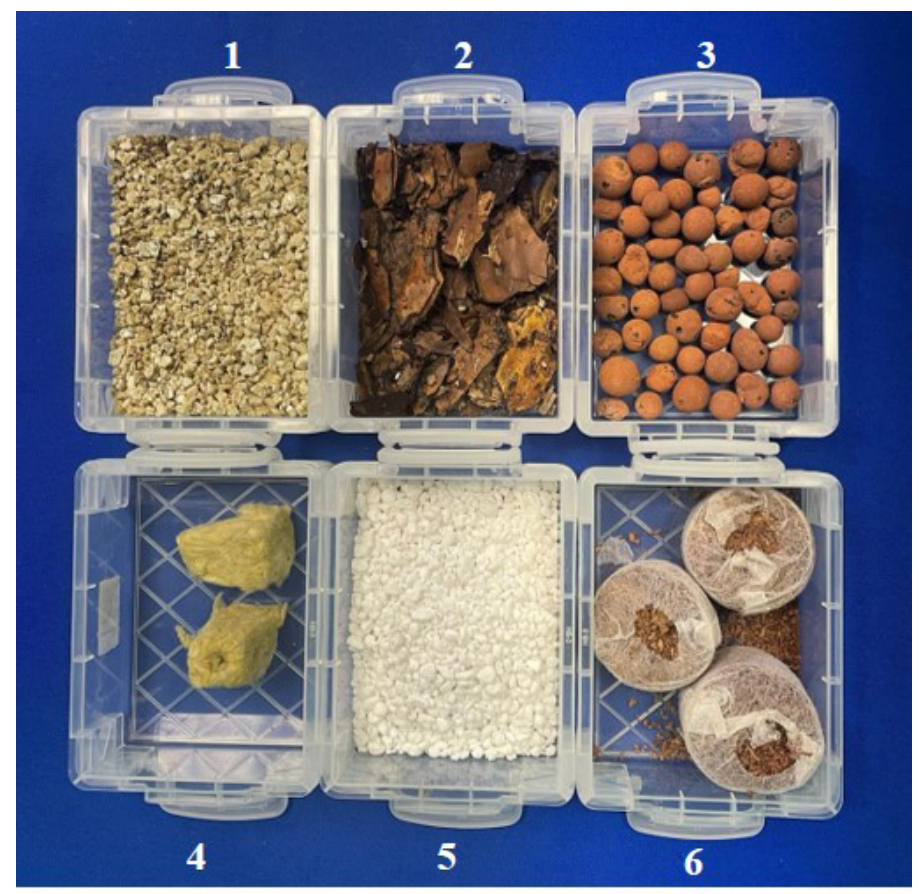

Figure 3. Examples of growing media for small hydroponics: vermiculite (1), composted pine bark (2), LECA (3), rockwood (4), perlite (5), and coconut fiber (6).

Credits: Jonael Bosques, UF/IFAS

1. Vermiculite-This material is the result of heated silica. At heating, the mineral forms thin layers where air and nutrient solutions can be held to interact with plant roots. This medium is excellent for root development and nutrient exchange. It is marketed in different grades ranging from fine dustlike particles to extra-coarse pellets.

2. Composted pine bark-This material is readily available in areas where there is a flourishing logging industry. Composted pine bark provides a medium for plant growth but can lower the $\mathrm{pH}$ of the solution. Also, inadequately composted or unfinished composting can sequester nitrogen $(\mathrm{N})$ from the solution, making $\mathrm{N}$ unavailable to the plant.

3. Light expanded clay aggregate (LECA) - “Clay beads," like perlite, are produced by heating clay to $2192^{\circ} \mathrm{F}$ in a rotary kiln (hence its shape). Trapped gases in clay make 
it expand and produce a honeycomb structure inside every pellet.

4. Rock wool-This material comes in cubes with prefabricated holes for seed placement. Rock wool is made by blowing molten rock, creating fibers that are spun and pressed into mats of inert minerals ideal for trapping water and air. Most rock wool products require soaking in a prepared $\mathrm{pH}$ buffer solution to remove the natural alkalinity of the media.

5. Perlite-This medium is made of natural volcanic glass pebbles that are porous. It is made by expanding rock via high temperature. Perlite is commonly used in potted plant mix to improve air and moisture holding.

6. Coconut fiber-This growing medium is derived from the coconut industry. This medium is also commonly used in nursery plant production. Coconut husks are ground and compacted to be shipped and marketed. It does provide a great substrate for air and water exchange by the roots, but as with the composted pine bark, it too can bind $\mathrm{N}$ and increase production costs. It comes in pellet form, brick form, and other products that can be incorporated in a home hydroponic system. Coconut fiber pressed into pellet and brick form requires a soaking period to expand the media prior to use.

7. River rock-This is the heaviest of all media. Fine river rock can provide surface for water to travel to the rootzone by capillarity but has very little water holding capacity.

Plant nutrition. As in soil systems, lettuce needs proper nutrition to produce a marketable and nutritious head. Many formulations are available on the market to provide the necessary amounts of $\mathrm{N}$, phosphorus $(\mathrm{P})$, and potassium $(\mathrm{K})$, or N-P-K, along with the other required plant macronutrients. Additional formulation of secondary nutrients and micronutrients might be needed to supplement nutrition. There are many formulations designed for hydroponic use. Home gardeners should evaluate a few and choose the one that best fits their specific needs. This evaluation should be based on yield and cost of production.

An important aspect to consider with the nutritional requirement for lettuce in hydroponics is the electrical conductivity (EC) of the solution. Regularly measuring and adjusting hydroponic EC can help homeowners accurately manage the nutrient strength of a hydroponic solution.
- Measuring the EC of the system is extremely important during solution formulation.

- Keeping a correct EC will avoid nutrient deficiencies, especially when using a recirculating system.

- For lettuce, the ideal EC ranges from 1.4 to $1.8 \mathrm{mS} / \mathrm{cm}$ and a $\mathrm{pH}$ of 6.0-7.0.

- For further information about EC, consult the following link: https://extension.okstate.edu/fact-sheets/electricalconductivity-and-ph-guide-for-hydroponics.html.

Supplemental lights. Supplemental lighting may be needed for optimal lettuce growth, especially when growing indoors or under partial shade (Figure 4). Lettuce cultivars developed for Florida conditions are adapted to 10-11 hours of light per day. Cultivars developed in northern latitudes may need extra time or hours of light.

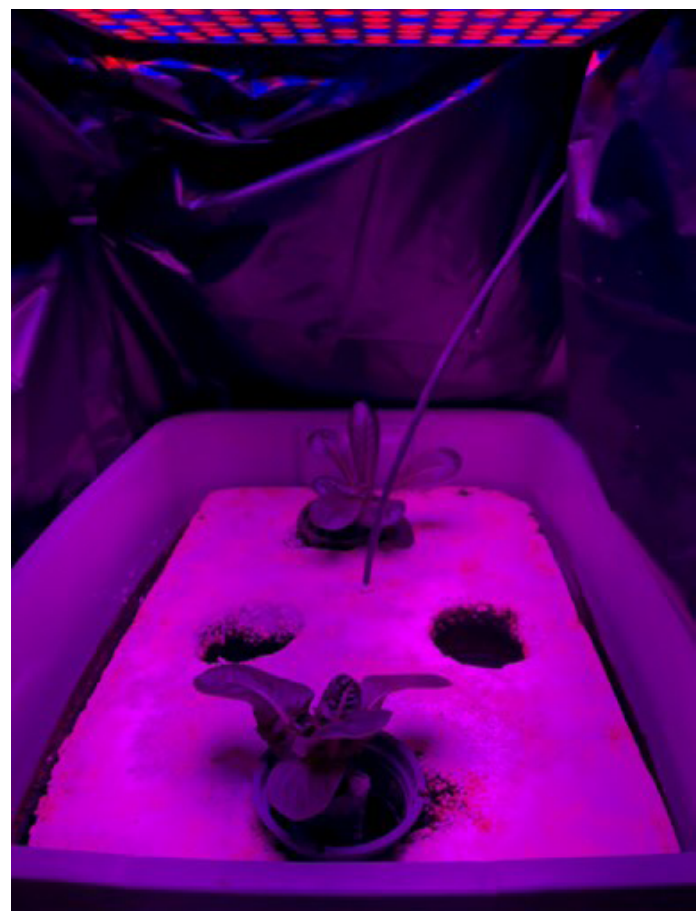

Figure 4. Lettuce grown under LED lights. Credits: Jonael Bosques, UF/IFAS

- Additional information on the recommended light spectrum and different sources can be found at https:// cea.cals.cornell.edu/lighting/.

- In small hydroponic settings, lighting adjustment may be needed. The following are guidelines that should be taken into consideration:

- Lighting too close to the seedlings can result in leaf burn.

- Lighting too far can result in spindly plants.

- Too much lighting time can stunt the plant growth and cause leaf distortion. 
Hydroponic system selection. Choosing a hydroponic system depends on budget, space, and crop.

- Budget-Prefabricated hydroponic systems are available on the market (Figure 3), or systems can be built at home to suit the gardener's needs.

- Space-There are vertical systems that are designed to produce lettuce in tiers. If space is not limited, there are many more choices to consider, each with its own advantages and limitations.

- Crop-Short-term crops (50-60 days) like lettuce can be grown in a wide array of systems. Long-term crops (>60 days) will be more difficult to grow and produce in hydroponic systems such as NFT or floating bed systems. Home gardeners should consider choosing the correct combination of $\operatorname{crop}(\mathrm{s})$ for the appropriate hydroponic system.

\section{Hydroponic Systems to Consider For Small Settings}

\section{Drip Irrigation System}

The use of drip irrigation lines allows gardeners to build hydroponic systems with relative ease and flexibility. With the addition of an irrigation timer, the system can precisely deliver each plant the adequate amount of water and nutrients needed. Some different setups include open drip systems and recirculating systems.

Open. The open system is a hydroponic production setup where nutritive solution is delivered through drip irrigation and the effluent is not captured and reutilized. The system consists of a primary irrigation line that in most cases is subdivided into secondary lines (depending on the system design). In most designs, emitters irrigate every pot (Figure 5), and they can be built with or without a collection channel.

Recirculating. The system includes a solution reservoir with an electric pump that allows the recycling of the nutritive solution multiple times. Monitoring the nutritive solution is needed to ensure that $\mathrm{pH}$, dissolved oxygen, and EC are optimal for plant growth in every stage of production (Figure 6).

Notice that drip system parts can be subject to clogging under hard water conditions. Constant inspection is required to ensure even distribution of water and nutrients to every plant. Verify the hardness of your water, and routinely check for issues with uneven distribution.

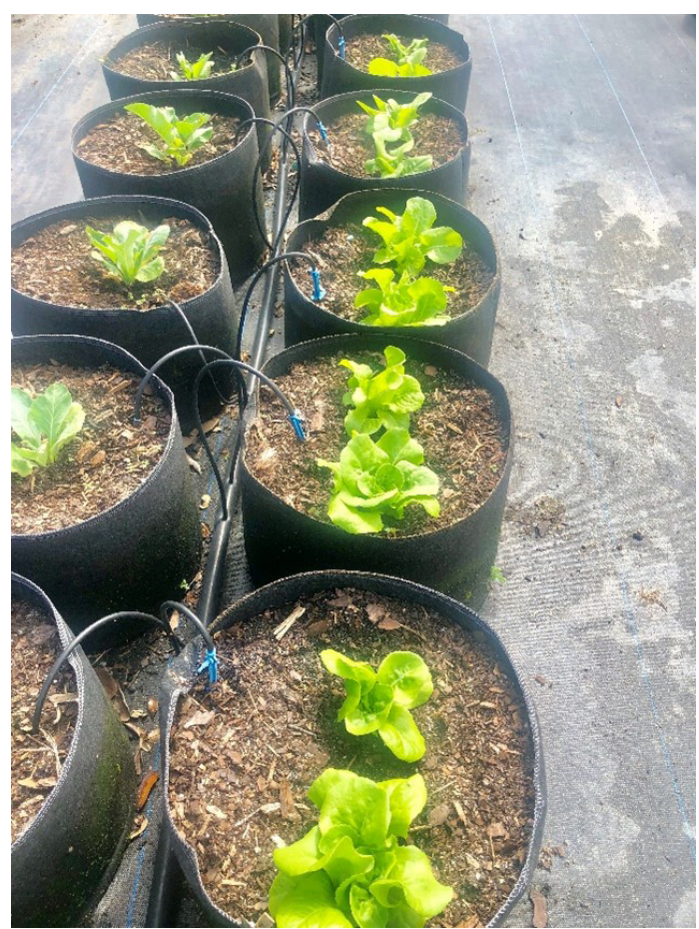

Figure 5. Open drip irrigation system to produce lettuce. Credits: Germán Sandoya, UF/IFAS

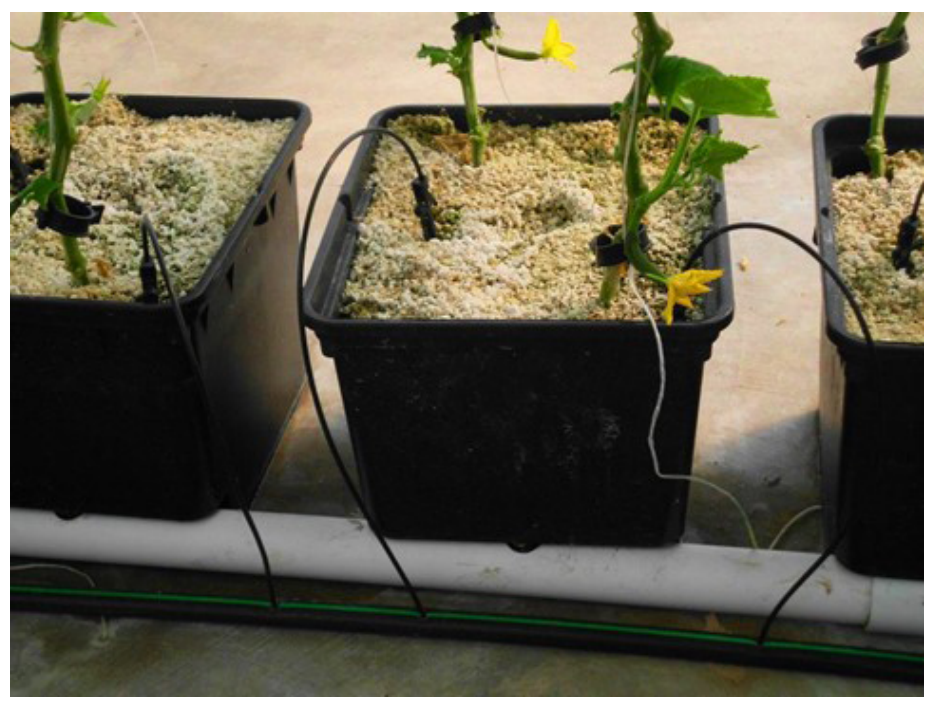

Figure 6. Bato Bucket recirculating system that can be adapted to grow lettuce.

Credits: Jonael Bosques, UF/IFAS

\section{Soil Mixed Raised Beds}

This system is ideal for lettuce because it is a short-term crop. Raised beds are more ergonomic than soil gardening and more comfortable to conduct all the practices required by the crop. The raised beds can be adapted to allow nutrient recirculation. Lettuce plants are arranged in rows under a protected structure (a greenhouse or open-sided grow house that helps reduce adverse effects of excess rain or other climatic events). Because the media can be mixed with compost, the raised beds may be planted with or without commercial fertilizer (Figure 7). 


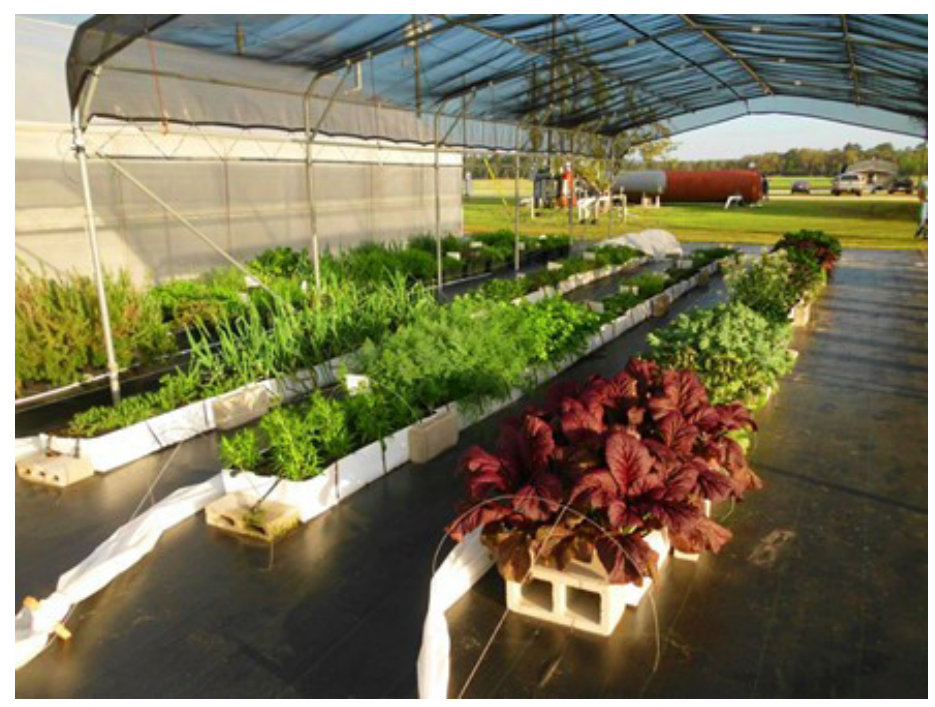

Figure 7. Soil mixed raised beds.

Credits: Jonael Bosques, UF/IFAS

\section{Nutrient Film Technique (NFT)}

The NFT is a water-culture technique that uses no media. The water with nutrient solution is recirculated and contained in PVC pipes and a holding tank. Home gardeners can purchase a prefabricated system (Figure 8) or choose to build their own. Besides the mentioned materials, gardeners may need timers and artificial lighting systems. The NFT system can be retrofitted for aquaponic production.

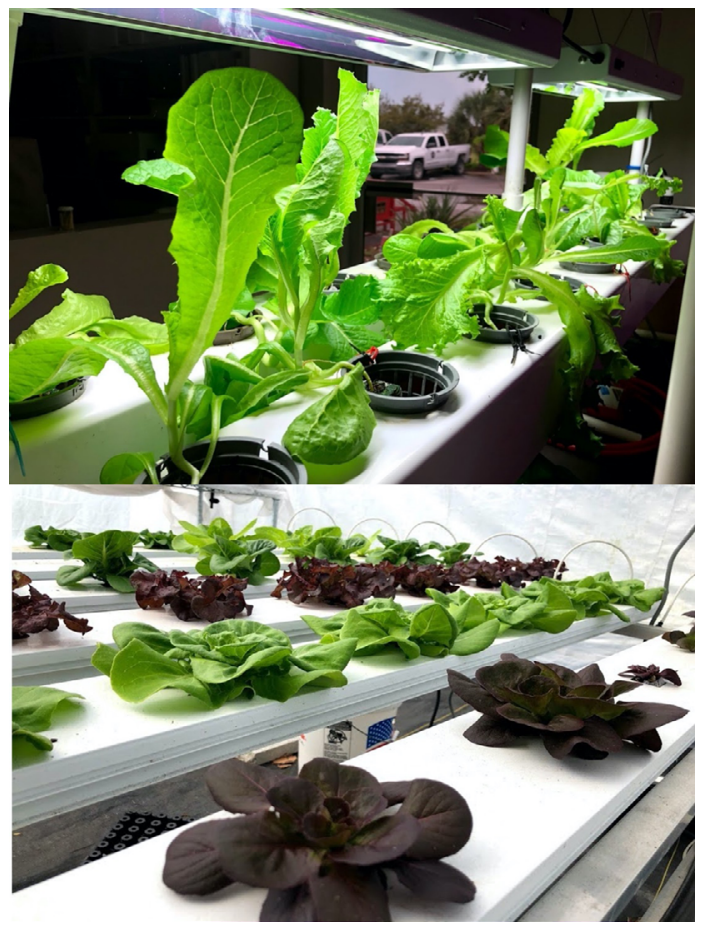

Figure 8. Two NFT systems to grow lettuce in small settings. The systems are prefabricated and can be purchased.

Credits: Jonael Bosques, UF/IFAS

\section{Floating Raft System}

This system utilizes a Styrofoam floating raft or mat with holes drilled. The nutrient solution is contained in a pool of nutrient-rich water. This system is ideal for short-term crops such as lettuce (Figure 9).

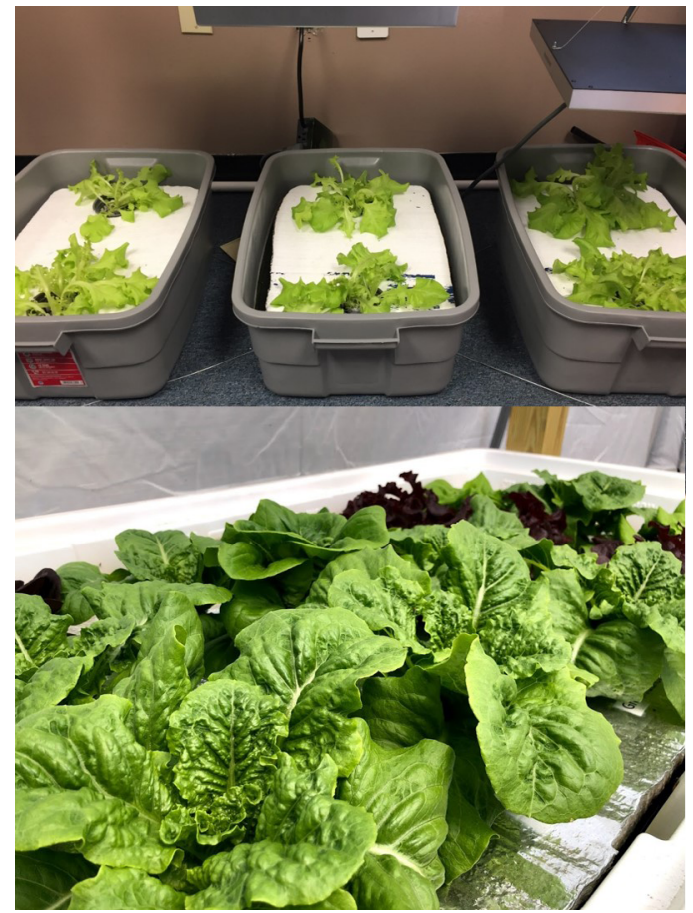

Figure 9. Two small rafting systems to produce lettuce in hydroponics. Credits: Jonael Bosques, UF/IFAS

Further information on how to build a floating raft system can be found in EDIS article HS943, Building a Floating Hydroponic Garden, at https://edis.ifas.ufl.edu/hs184 (Sweat, Tyson, and Hochmuth 2003).

Items Needed:

- Raised bed

- Plastic liner ( 3 or $6 \mathrm{ml}$ )

- Styrofoam surface (2 inches thick)

- Ground cover

- Aerator and air stone

\section{Vertical System}

This system is designed to produce crops in vertical rows irrigated from the top. Gardeners can increase plant populations if space is a limitation. The system includes vertical bags or stacked pots (Figure 10).

Notice that lighting can be a major issue due to shading of the lower plants. Lack of consistent airflow can also decrease productivity and cause fungal and bacterial disease outbreaks throughout the production cycle. 


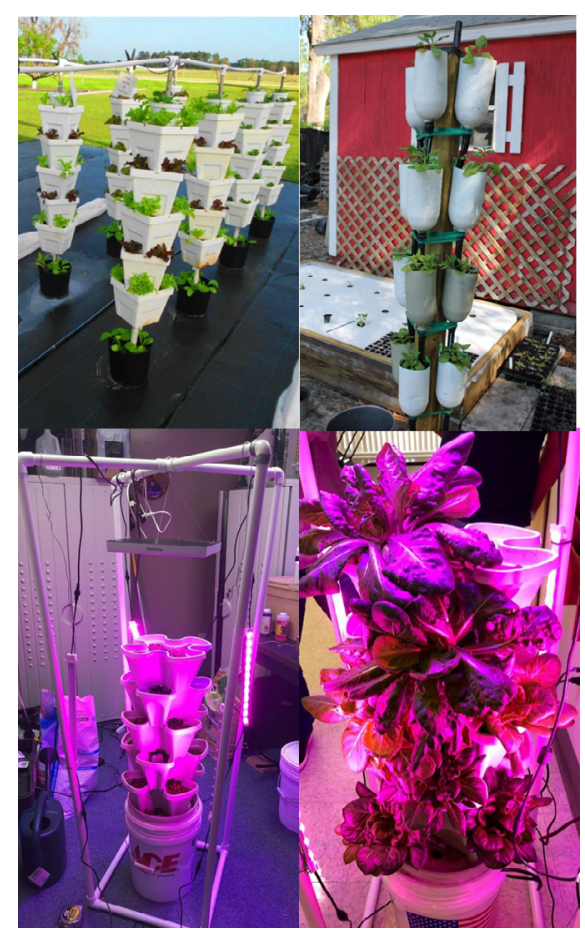

Figure 10. Vertical tower to grow lettuce outdoor and indoor with supplemental lighting.

Credits: Jonael Bosques, UF/IFAS

Items Needed:

- Stackable containers

- Containers for nutrient solutions

- Irrigation system

- Growth media

\section{Further Considerations}

- Nutritive solution should be constantly monitored for temperature, which should be maintained between $65^{\circ} \mathrm{F}$ and $80^{\circ} \mathrm{F}$. The solution should have good oxygenation (dissolved oxygen $=5 \mathrm{mg} / \mathrm{L}$ ) and EC between 1.2 and $1.8 \mathrm{mS} / \mathrm{cm}$ (560-840 ppm). Gardeners should consider purchasing a conductivity/pH meter and a dissolvedoxygen meter. There are a broad range of meters, and some will measure all three values.

- Irrigation time/amount-Too much water can cause root rot in some systems such as NFT. Constant irrigation will not be necessary in most systems. An automatic irrigation timer may be needed for NFT, vertical towers, and other hydroponic systems.

- Scouting-It is believed that vegetables such as lettuce produced in a controlled environment (hydroponic) should have a lower incidence of pests and disease. If a pest or disease is identified, follow an Integrated Disease/ Pest Management approach that includes scouting, monitoring, and control when recommended. Plant certified seed that is pathogen- and pest-free. Consult your specialists at UF/IFAS for further identification and guidelines. Several UF/IFAS EDIS publications offer valuable recommendations to prevent and control pests and diseases: see Considerations for Managing Greenhouse Pests at https://edis.ifas.ufl.edu/cv248 and Vegetable Insect Identification and Management at https://edis.ifas.ufl.edu/ cv274 (Rich et al. 1990; Webb and Hochmuth 1990).

\section{Additional Resources}

Resources on small farms may provide useful information for home and urban gardeners in several aspects presented in this publication. Small-farms information can be found at the UF/IFAS small-farms website: https://smallfarm.ifas. ufl.edu/.

The Hydroponic Lettuce Handbook contains information on hydroponic lettuce: https://cpb-us-e1.wpmucdn.com/ blogs.cornell.edu/dist/8/8824/files/2019/06/Cornell-CEALettuce-Handbook-.pdf. While most of the information is intended for commercial greenhouse operations, home gardeners may extrapolate these recommendations into smaller settings.

For further information, contact your UF/IFAS Extension vegetable specialist.

\section{References}

Rich, J. R., S. E. Webb, M. L. Paret, and T. M. Momol. 1990. "Considerations for Managing Greenhouse Pests-Florida Greenhouse Vegetable Production Handbook, Vol 3.” EDIS 2013 (5). https://edis.ifas.ufl.edu/cv248

Sweat, M., R. Tyson, and R. Hochmuth. 2003. "Building a Floating Hydroponic Garden.” EDIS 2004 (1). https://doi. org/10.32473/edis-hs184-2003

Tyson, R., R. Hochmuth, and D. Cantliffe. 2010. "Hydroponic Vegetable Production in Florida." EDIS 2010 (1). https://journals.flvc.org/edis/article/view/118314

USDA National Agricultural Statistics Service. 2020. "State Agricultural Overview." Accessed 10 March 2021. https:// quickstats.nass.usda.gov/

Webb, S. E., and R. Hochmuth. 1990. "Vegetable Insect Identification and Management-Florida Greenhouse Vegetable Production Handbook, Vol 3." EDIS 2010 (4). https://journals.flvc.org/edis/article/view/118660 